Article

\title{
The Challenge of Food Systems Research: What Difference Does It Make?
}

\author{
Ruerd Ruben ${ }^{1, *}$, Jan Verhagen ${ }^{2}$ and Christine Plaisier ${ }^{1}$ \\ 1 Wageningen Economic Research, Wageningen University \& Research, P.O. Box 29703, 2502 LS The Hague, \\ The Netherlands; christine.plaisier@wur.nl \\ 2 Wageningen Plant Research, Wageningen University \& Research, P.O. Box 35, 6700 AA Wageningen, \\ The Netherlands; jan.verhagen@wur.nl \\ * Correspondence: ruerd.ruben@wur.nl; Tel.: +31 (0)70-361-5624
}

Received: 30 November 2018; Accepted: 23 December 2018; Published: 31 December 2018

check for updates

\begin{abstract}
Recent discussions on the results of food security programs devote key attention to complex interactions between policy interventions and business innovation for improving nutrition outcomes. This shift from linear approaches of food and nutrition security towards a more interlinked and nested analysis of food systems dynamics has profound implications for the design and organization of research and innovation processes. In this article we outline our experience with interdisciplinary and interactive processes of food systems analysis at different scale levels, paying systematic attention to three critical system interfaces: intersections with other systems, interactions within the food system, and incentives for food system innovations (the so-called: 3I approach). We discuss the importance of these interfaces for leveraging food system adaptation and managing food system transformation. We also provide illustrative examples of the relevance of food systems analysis for the identification of appropriate and effective programs for reinforcing the resilience, responsiveness and inclusiveness of novel food and nutrition programs.
\end{abstract}

Keywords: food systems; interdisciplinary research; feedbacks \& interlinkages; food policy; 3I Approach

\section{Introduction}

Research and policy on food security has long been dominated by questions regarding availability, access and utilization. Major attention has been given to the identification of key factors that influence the availability of food at different levels (i.e., individual, household, region, country), and the likely implication of the growth of world population for food security [1]. Other studies focus on understanding of processes that reinforce access to food and/or improve food utilization. Less attention is devoted to the multidimensional nature of food security as influenced by interactions between technical, economic, social and cultural factors. Moreover, the rather linear nature of many food security analyses (focusing mainly on intensification of food production) is increasingly challenged by more complex causal mechanisms that focus on competing goals, emerging system properties and dynamic feedback mechanisms [2].

Food systems include all elements and activities related to the production, processing, distribution, preparation and consumption of food, the market and institutional networks for their governance, and the socio-economic and environmental outcomes of these activities [3-5]. Food systems analysis is based on systematic appraisal of different underlying processes that influence food availability, access and utilization, as well as a detailed analysis of the roles of different stakeholders involved, notably the role of the consumer in nutrition-oriented food systems. It requires a thorough understanding of the structure of a food system and the dynamics of food system changes over time and space in 
relation to predefined societal, environmental or distributional goals. Important pillars for adequately linking food system analysis to nutrition policy are [6-8]:

- Household targeting: focus on nutritional outcomes for different categories of consumers (differentiated by wealth, gender and age) that have particular types of dietary preferences;

- Multiple delivery pathways of food: food access is satisfied through a combination of home production, open markets purchase, supply by retail and supermarkets, and out of home consumption from restaurants and food services;

- Interactive governance of material flows and information exchange networks between different stakeholders and steering of decision-making processes by the food systems environment;

- Diet implication: effects on dietary intake and possible nutritional imbalances resulting from the combination of diverse baskets of food products.

In this article we aim to assess the conceptual challenges and practical opportunities for analysing the structure and performance of food systems, and we identify how food systems analysis could deliver new and innovative insights for nutrition policy in developing countries. The main objectives of the article are (a) to identify the strategic interfaces between different levels of the food system, and (b) to assess food system responses to business innovations or policy interventions. Therefore, the article responds both to the analytical challenge of understanding food systems performance as well as the empirical challenge of identifying appropriate public and private actions for supporting food systems change in line with societal goals. Moreover, we outline a framework to explore pathways of food system adaptation and to assess the dynamics of food systems transition that goes beyond the mere description of alternative options. This permits us to explicitly acknowledge trade-offs between production and nutrition goals, and may support active engagement of public and private stakeholders [9].

In a conceptual sense, food system analysis is usually conducted in a context where different goals and ambitions are simultaneously pursued and trade-offs between system objectives are likely to occur. Clear understanding of the interdependencies between different stakeholders (i.e., producers, traders, processors, consumers, policy makers) is required for adequately tracing how activities (material and human inputs) translate into desired outcomes (food security results and impact on nutrition). System boundaries should be acknowledged to identify the feasible solutions space. Changes at one system level might lead to undesirable results elsewhere in the food system, and improved knowledge on these interactions could possibly give rise to other types of interventions.

In a practical sense, food systems analysis asks for support from a wide variety of disciplines and also requires the involvement of multiple stakeholders. The willingness to cooperate is usually based on beliefs and expectations that such a research process provides innovative outcomes and more relevant insights. Moreover, the engagement of other (non-science) parties in the research process enables better feedback and linkages to policy and practice [10]. This type of broad multi-stakeholder cooperation and knowledge exchange is considered particularly important for understanding adaptive processes that depend on interaction between technical and behavioral drivers of food system change.

The remainder of this article is organized as follows. In Section 2 we outline the analytical framework for adequately understanding food system structure and dynamics, showing the importance of interlinkages and feedback mechanisms. We briefly assess different methodological strands within food systems analysis and indicate their prospects for food policy appraisal. Section 3 discusses the requirements for collaborative research around critical system interfaces that enable the analysis of food systems performance. In Section 4 we translate this framework for food systems analysis towards food and nutrition policy outcomes and identify some key areas where major differences with traditional food security programs become visible. Finally, in Section 5 we present a theory of change for analysing food systems dynamics to pursue different development trends, and we summarize in Section 6 the advantages of our food systems approach for better dovetailing 
public and private actions and for capturing potential trade-offs between different societal goals in a timely way.

\section{Understanding Food Systems Performance}

Most analyses of agricultural development start by addressing opportunities for increasing the production of food either by increasing the cultivated areas (extensive growth) and/or through higher yields (intensive growth). Much attention is usually given to agronomic research around the design and extension of farming systems that have the capacity to generate higher returns from land. The latter approach has been complemented by economic research focusing on the identification of appropriate incentives and policies to support input use by local smallholders (seeds, fertilizer, credit) towards higher returns from family labour and greater overall factor productivity (i.e., output generated by all production factors together).

At the end of the 1990s, intensive international debates around the Millennium Development Goals (MDGs)-later on followed by 'Zero Hunger' challenge as part of the Sustainable Development Goals (SDGs) - asked for wider understanding of the different pathways towards food security. This was not only because a single goal (food availability) was complemented with additional dimensions (food access; food utilization; food safety), but also because aspects of time (stability) and space (environmental resilience) increasingly required attention.

Food systems research took off when strategies for supporting food supply (production) and food demand (consumption) began to be simultaneously analysed within an integrated analytical framework. Trade-offs between these goals and tensions between instruments have been frequently registered, for instance with respect to prices (i.e., high prices to support producers affect consumer demand for food) and for supporting investments (i.e., low interest rates support input use but may reduce employment). This becomes even more complicated when specific outcomes for well-defined target groups (i.e., vulnerable households; people in remote areas; urban populations; women) are pursued, or when agriculture is supposed to contribute to wider societal goals (nutrition, health, employment, environment and climate).

Food systems analysis has undergone important changes over the last few decades. Three different strands and related narratives can be distinguished: (a) descriptive analysis of the structure of food systems with emphasis on the identification of key components [11-13]; (b) explorative analysis of different policy options and opportunities for improving food systems performance [14-17], and (c) interactive analysis of food system transitions and adaptive innovation strategies for creating synergies and coherence between key agents [18-20]. While there is still limited communication between these narratives-also related to the different academic disciplines underlying each of them (i.e., agro-ecology, economics, nutrition and sociology)—it is urgently needed to reinforce our understanding of feasible and effective strategies for supporting transitions towards healthier and sustainable diets [21,22]. This calls for approaches that allow to bridge the gaps between hard and soft systems analysis and that are capable of blending multi-level and multi-stakeholder dynamics [2].

Whereas many recent studies focus on the characteristics and features of food systems [23-25], we consider it more useful to analyse which are the main dilemmas for making the food systems framework useful for overcoming dilemmas in public policy and business practice [26]. Therefore, we introduce a distinction between food system adaptation and food system transformation to highlight different types of responses and interventions that underpin the design of food policies and innovations [27,28]. Adaptation of interactions between food system components may enable timely adjustment to key bottlenecks, whereas external shocks call for major structural transformations. Such a dynamic approach to food systems change can be particularly helpful to engage multiple stakeholders into a common and coherent strategy that satisfies their long-term objectives [29].

Food systems analysis has been applied in two different arenas: for scaling public nutrition policies and to support food business learning platforms and innovations networks. Therefore, different leverage points need to be identified that generate enduring improvements in food systems 
performance. The relevance and effectiveness of this framework can be demonstrated by the emergence of new forms of multi-stakeholder coalitions that support food system adaptation (see Section 4) and the multi-level food systems transformations and responses to different types of external shocks (see Section 5). The initial representation of food systems was based on a fairly linear understanding of the linkages between food supply and demand activities (See Figure 1). It reflected an increasing awareness that different stakeholders in the supply chain perform specific functions for providing access to key inputs, processing primary outputs, and the marketing and distribution of food towards final consumers. The original material and energy flow approach has been complemented in more economic terms by analyses of the value chain [30] that looks at the transactions between stakeholders and analyses the price and non-price properties of exchange conditions (trust, reliability, frequency, etc.).

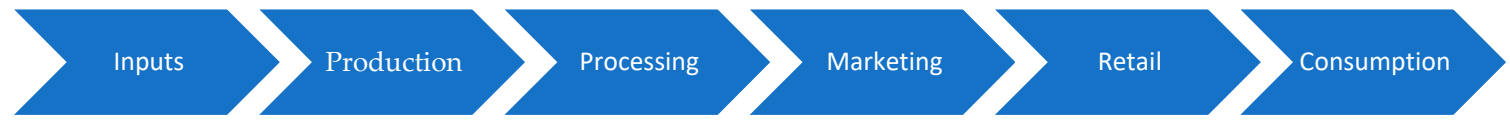

Figure 1. Linear food supply system.

Whereas the supply/value chain framework improved the understanding about (horizontal) interdependencies, it still provides little insight into system interactions and feedbacks. Also, externalities for the society and the environment need more attention. The inclusion of waste recovery and nutrient recycling into the model means that the system is better described with a circular representation (see Figure 2). This also enables us to capture better the linkages between (intermediary) inputs and outputs that are relevant for improving food system efficiency.

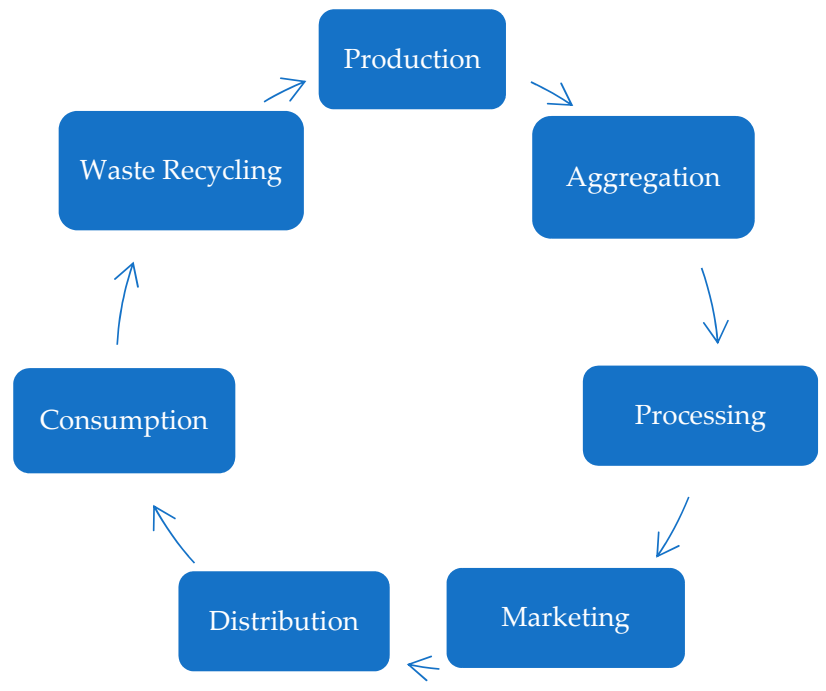

Figure 2. Circular food system.

It was rapidly acknowledged that these linear and circular frameworks cannot do full justice to the multiple levels and dynamic interlinkages between food production and nutrition, especially because they disregard important spatial and temporal interactions [31]. Therefore, different efforts were made to develop a more 'nested' approach to food systems as part of a set of wider sub-systems. This includes both downstream linkages towards soil dynamics and their environmental and climate effects, as well as upstream linkages within village and regional governance regimes and the linkages of food to labour and capital markets that influence to a large extent the potential inclusiveness of food systems.

The recognition of the importance of systems dynamics and feedback mechanisms incited a range of complex multi-level graphic representations and related modelling exercises [32,33]. Food systems 
are increasingly visualised as networks that provide environmental services, enhance human welfare and promote community-based socio-economic development, and thus contribute to sustainability, resilience and equity [34]. Food choices and dietary outcomes are embedded in household/family dynamics and village/regional conditions, whereas the availability and the supply and demand of food is strongly governed by the food environment (see Figure 3).

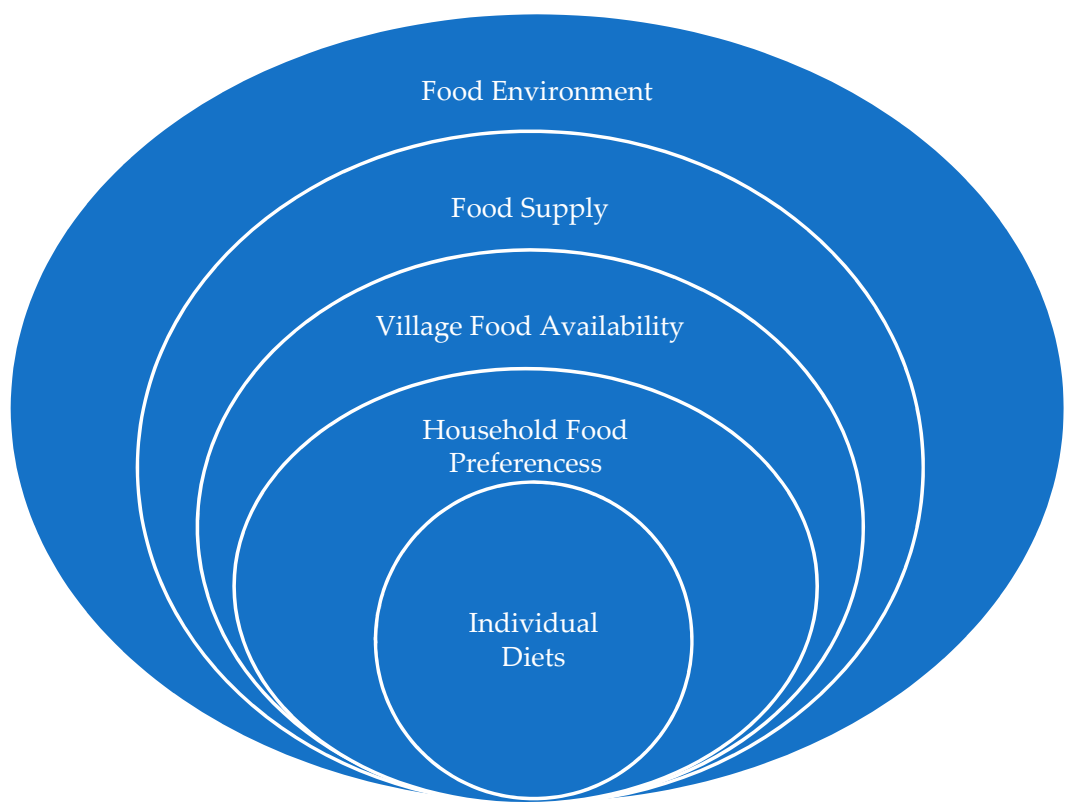

Figure 3. Nested food system.

This integrated framework of food systems has been embraced by major international fora, like by the Committee on World Food Security (CFS), the High Level Panel of Experts on Food Security and Nutrition (HLPE) and the Global Panel on Agriculture and Food Systems for Nutrition (GLOPAN). It is considered a useful framework for understanding major interactions at five different levels of the food system:

- Physical food supply chains responding to behavioural preferences;

- Material food flows generating information on availability and prices;

- Price and non-price incentives that influence household demand;

- Resources (inputs) that are required for enabling reliable food supply;

- Policy and institutional environment that shape individual food choices.

Using a food systems approach for policy analysis has profound implications. This is not only because multiple-sometimes conflicting — goals need to be considered, but also because several external factors (demography, urbanization, infrastructure, economic growth, climate change) influence to a great extent the internal food systems dynamics [35]. This calls for an in-depth analysis of potential trade-offs and/or possible synergies between healthier diets, sustainable resource management, resilient food systems and inclusive development [36]. Therefore, a combination of modelling tools (scenario development) and lab-in-the field (behavioural experiments) approaches need to be used to enhance our insights into the interactions and feedback mechanisms of food systems.

\section{Interfaces for Food System Analysis}

Based on our understanding of the structural features of food systems, we can now identify the analytical framework to conduct empirical research on food systems dynamics. Given the complexity of nested interactions between system levels and stakeholders, it is considered most useful to organize research as part of a concrete intervention framework. This implies that we advocate for 'Research 
in Development', not as a sequential process but as an interactive approach to understand system interfaces through direct stakeholder involvement.

Taking stock of the experiences from the Wageningen Research knowledge base (KB) program on global food and nutrition systems, we discuss three strategic interfaces-the so-called 3 I framework - that are critical for identifying and understanding leverage points towards food systems change:

a) Intersections with other non-food systems that influence the supply and demand of food;

b) Interactions between stakeholders that are engaged at different levels of the food system;

c) Incentives that influence the adaptive behaviour and response of food system stakeholders.

(a) Intersections with Other Systems

In the first place, any adequate analysis of the food systems dynamics requires a thorough understanding of intersections with other systems. This refers both to horizontal linkages at space or landscape level, as well as to vertical linkages with non-food systems (such as local labour markets or international trade perspectives). It implies that the performance of the food system will be influenced by several types of 'external' events that shape to a certain extent the internal dynamics of the food system. Some critical events in other systems that are likely to occasion major food system shocks are:

- Population dynamics such as migration, leading to spatial shifts in food demand between rural and urban populations;

- Economic (income) growth, that will influence food preferences towards demand for more processed food and more food purchased at supermarkets;

- Technological development (i.e., ICT) that may open new, sometimes unforeseen, opportunities for food production, distribution and sales;

- Climate change that may lead to spatial adjustment of appropriate production locations and/or requirements for reorganization of the supply chain.

These external trends shape the opportunities for modifying food production and food distribution, and also create new spaces for diversifying food demand. These external trends may either reinforce or balance the changes in internal dynamics of the food systems. Urbanization and economic growth tend to reinforce demand for more animal-based diets and processed food, whereas technological change has the potential to improve the efficiency in food production and distribution. Climate change, on the other hand, could modify the production potential and even lead to changes in feasible production locations, and thus has direct effects on food supply and food prices.

(b) Interactions within the Food System

In the second place, interactions of activities exist between different stakeholders within the food system. Food systems outcomes are shaped by activities at different system levels, and desired outcomes sometimes require 'remote' interventions that generate results elsewhere in the system. A food systems approach can be helpful to identify and promote activities that are beneficial to desired outcomes, and should also consider alternative activities based on possible trade-offs with other outcomes. Typical examples of such multi-level interactions that generate different outcomes at different system levels are:

- Food waste reduction efforts made by primary producers tend to pay-off elsewhere in the supply chain through improved margins for retailers (due to longer shelf life);

- Healthier dietary choices may be supported through direct consumer targeting (vouchers; subsidies), but this could be done in a more cost-effective manner by reinforcing the food supply environment (retail design, peer norms);

- Food safety assessments by consumers are largely based on trust that adequate risk management practices are taken in upstream activities (processing, trade, storage). 
Adequate understanding of these interactions within the food system enables a more strategic selection of focal points for influencing food system outcomes. Given these interdependencies between stakeholders, healthier or more sustainable diets can be promoted by modifying exchange conditions for food transactions. This refers both to price and non-price characteristics for supply and demand of food that may lead to changes in production practices and/or consumers' preferences. Stakeholder cooperation could reinforce alliances between food system stakeholders (convergence) but also conflicting outcomes are possible.

(c) Incentives towards Food Systems Stakeholders

In the third place, food system analysis asks for a clear understanding of the effectiveness of incentives for stakeholders to change behaviour and to make choices or implement activities that are needed to achieve the defined goals. Since food systems change can be supported by different types of incentives (prices, taxes/subsidies, information, laws) that influence stakeholders into different directions, it is quite possible that conflicting signals are given and, therefore, that not all system outcomes can be reached simultaneously. Some of these common food system trade-offs refer to:

- Cooling during transport and storage of fast-moving perishable consumer goods such as fresh vegetables and dairy (healthier food) is more demanding in terms of energy use (less sustainable);

- Healthier food choices are hard to influence with market incentives and depend to a large extent on social norms;

- Investments in better waste management tend to increase overall market availability that leads to lower producer prices, thus taking away the initial incentive for engagement.

For the identification of suitable incentives towards healthier diets and sustainable food systems, it is important to understand direct response reactions from producers and consumers, but also spillover effects to other food system stakeholders and the general equilibrium effects on market prices. These secondary implications may either reinforce or counterbalance the original incentive structure and thus determine to a great extent the overall system outcome.

This so-called 3I framework can be very useful to support information exchange between academic disciplines and to foster active engagement of multiple stakeholders [37]. It is also relevant for steering food system policy analysis where insights regarding technical feasibility and behavioural responses need to be simultaneously considered. In addition, different food system goals (such as sustainability, inclusiveness, fairness and resilience) may be compared with respect to their potential trade-offs. Finally, adequate understanding of interactions between different system levels (food production, value chains, food consumption) is helpful to identify the role of different stakeholders (public policy, civic advocacy, business networks) for supporting food system innovations [38].

The food systems analysis thus considers some of the key variables and their major potential interactions as underlying factors influencing dietary choices (by consumers) and allocative choices (by producers and processors). It outlines clearly that effective policies for food system adaptation and transformation require coordinated actions by different public and private stakeholders.

The food system approach might also be a useful framework to identify game changers for improving systems performance. It enables better understanding of both positive and negative feedbacks and considers behavioural interactions that shape the stakeholder's responses to external incentives or shocks. Systems change can thus be based on understanding thresholds and managing the tipping points [39]. The latter are sometimes real regime shifts: large, often abrupt and non-linear changes in food systems behaviour, usually triggered by conflicts between social and environmental factors (poverty traps; ecological shocks) that directly affect people's livelihoods [40]. This understanding is important to identify possible instruments and innovations that are proposed to support food system improvements. 


\section{New Insights on Food Systems Performance}

Food systems analysis is expected to deliver new insights for a more accurate process of public policy formulation and private sector investment appraisal. It is increasingly seen as a suitable way to improve food systems' outcomes (in terms of inclusiveness and sustainability) in order to deal with competing priorities (healthy and sustainable diets) and to harmonize complex interfaces that exist between the stakeholders within food systems [41-43].

Therefore, it is useful to ask the question: what differences does it make to rely on food systems analysis for the selection of public policy and private investment priorities, and which instruments and incentives can be used to support these objectives? We focus on five food systems levels that are of critical importance for internal interaction, and distinguish between different types of interventions (or leverage points [44]) that focus on (a) supply-led production logic and (b) demand-led food consumption logic (see Table 1). For each approach we also indicate the most likely stakeholder coalition to harmonize multi-level policy interventions.

Table 1. Interventions to improve food system performance.

\begin{tabular}{|c|c|c|c|}
\hline Leverage Point & Conventional Logic & Food System Logic & $\begin{array}{l}\text { Multi-Stakeholder } \\
\text { Coalition }\end{array}$ \\
\hline Production systems & $\begin{array}{l}\text { (a) Focus on improving } \\
\text { inputs (seed, fertilizers) } \\
\text { and training in good } \\
\text { agricultural practices } \\
\text { (GAP) for yield } \\
\text { improvements, shifting } \\
\text { towards more } \\
\text { commercial agriculture }\end{array}$ & $\begin{array}{l}\text { (b) Focus on (local and } \\
\text { external) market demand } \\
\text { that generates incentives to } \\
\text { pull-in farm-level } \\
\text { investments and reinforce } \\
\text { farmers' bargaining position }\end{array}$ & $\begin{array}{l}\text { (a) Producer-based with } \\
\text { (private and public) } \\
\text { support services } \\
\text { (b) Marketing } \\
\text { cooperatives and } \\
\text { contract farming }\end{array}$ \\
\hline Value chains & $\begin{array}{l}\text { (a) Income generation } \\
\text { and value added } \\
\text { generation by upgrading } \\
\text { and sales with private } \\
\text { processors and traders } \\
\text { networks }\end{array}$ & $\begin{array}{l}\text { (b) Reinforce local } \\
\text { processing and strengthen } \\
\text { (female) bargaining to } \\
\text { generate higher value added } \\
\text { and improve } \\
\text { intra-household welfare }\end{array}$ & $\begin{array}{l}\text { (a) Midstream input } \\
\text { providers and traders } \\
\text { (b) Farmer organization } \\
\text { \& trade contracts }\end{array}$ \\
\hline Distribution networks & $\begin{array}{l}\text { (a) Guarantee stable } \\
\text { market outlets through } \\
\text { guaranteed quality and } \\
\text { delivery loyalty }\end{array}$ & $\begin{array}{l}\text { (b) Develop long-term } \\
\text { upstream/downstream trust } \\
\text { relationships and stable } \\
\text { revenue streams }\end{array}$ & $\begin{array}{l}\text { (a) Trader-oriented } \\
\text { contracts } \\
\text { (b) Producer-trader } \\
\text { interface }\end{array}$ \\
\hline Household livelihoods & $\begin{array}{l}\text { (a) Support to higher } \\
\text { land productivity and } \\
\text { income generation } \\
\text { trough specialisation } \\
\text { with higher farm } \\
\text { employment }\end{array}$ & $\begin{array}{l}\text { (b) Support to higher labour } \\
\text { productivity with education } \\
\text { and risk reduction through } \\
\text { (on/off farm) activity } \\
\text { diversification }\end{array}$ & $\begin{array}{l}\text { (a) Public land titling } \\
\text { and private input } \\
\text { providers } \\
\text { (b) Village networks and } \\
\text { civic agencies }\end{array}$ \\
\hline Food choices & $\begin{array}{l}\text { (a) Attention to food } \\
\text { security through supply } \\
\text { and stable access to } \\
\text { sufficient, affordable } \\
\text { (and safe) food }\end{array}$ & $\begin{array}{l}\text { (b) Attention for informed } \\
\text { choices for healthy and } \\
\text { varied diets through home } \\
\text { production and market } \\
\text { purchase }\end{array}$ & $\begin{array}{l}\text { (a) Public infrastructure } \\
\text { and private retail } \\
\text { (b) Food environment } \\
\text { and behavioural change } \\
\text { communication (NGOs) }\end{array}$ \\
\hline
\end{tabular}

Source: author's elaboration.

Programs that focus on improving farm production systems usually devote major attention to the input side (better seeds and fertilizers to support the adoption of improved agricultural practices) enabling producers to earn higher incomes through engagement in commercial farming. Better results might be achieved if due attention is also given to incentives from the market environment (e.g., de-risking) that incite farmers to make the necessary investments and reinforce their bargaining position in major markets. The latter interventions are likely to deliver better results in terms of 
household consumption and dietary intake that are strongly driven by certainty on revenue streams and risk diversification from engagement in different market outlets.

Interventions at the level of value chains are critically important to guarantee that farmers can reap the product of their investment efforts. In practice, however, a large proportion of the generated value added accrues to upstream chain actors. In addition to value chain integration and upgrading, it is important to guarantee that women receive a fair share of the generated revenues. This is a key condition to guarantee that higher revenues are translated into better nutrition and improved household welfare [45].

The organization of food distribution networks also influences dietary outcomes. Traditional marketing programs focus on reaching scale, reinforcing quality and strengthening loyalty between producers and processors (avoiding free riding and sides sales). Food systems approaches recognize also the importance of social and cultural interfaces and thus support trust and loyalty as initial conditions that enable smallholders to make farm-level investments for improved production systems.

In a similar vein, many programs that focus on household livelihoods tend to search for higher land productivity, usually through a higher degree of activity specialization and more on-farm employment. However, rural households look to optimize utility and thus search for higher labour productivity, also off-farm and outside agriculture (i.e., more revenues and higher leisure), and benefit particularly from engagement into risk-reducing activities. To enable smallholders' adoption of high-yielding activities, social and commercial networks are of vital importance.

Finally, improving individual food choices requires first of all better availability of (different types of) food and stable access to affordable, safe and healthy food items. While this is a necessary condition for supporting food choice, it is certainly not a sufficient condition for realizing such an outcome. Therefore, demand-side interventions are also required that reinforce the food environment and provide information and incentives to individuals and households for improving behavioural choices.

In summary, the food system approach provides an analytical framework that gives new insights in intervention pathways which enrich the 'menu of opportunities' for linking key food policy instruments and for involving different stakeholders. This will enable a better understanding of the interactions between the material and behavioural drivers of food systems change that are vital for linking food production, exchange and consumption, to identify effective food governance mechanisms and to assist stakeholders to make better informed choices on resource allocation and investment.

The involvement of different (public, private and civic) stakeholders is required to guarantee that supply and demand-side requirements of food systems are balanced. Moreover, public support programs need to be embedded into business drivers for innovation to safeguard food systems responsiveness. These new insights are generated by using systematically the analytical food systems lens that identifies more effective pathways towards food systems transformation in line with stakeholders' perceptions and societal development goals.

\section{Drivers for Food System Change}

The usefulness of food systems analysis can also be assessed within a more dynamic framework by looking at how food systems respond to some major external drivers of change (urbanization; economic growth; climate change; information and communication technology (ICT) connectivity). This analysis of pathways for food system transformation is based on understanding of how external change may lead to adjustments within the food system, and what type of adaptations are likely to take place in different layers (i.e., individual, household, village, region and value chain) of the food system as outlined in Figure $3[15,18]$. Food system responses are thus of critical importance to guarantee that trade-offs between conflicting aims can be reconciled and competing claims on resources are overcome [46,47].

We distinguish three areas of responses to major trends that together determine the adaptive capacity of food systems: resilience capacity, inclusiveness, and sustainability (see Table 2). As shown in Table 2, the suggested responses to external shocks are not isolated and limited to particular stages in 
the food supply chain, but make use of the interlinkages and feedback within the nested food system. Looking at intersections with other systems, interactions within the food system, and incentives towards food system stakeholders leads to other types of responses and invites different types of interventions (see also Section 3) that might be overlooked in more conventional food chain and network analysis.

Table 2. Examples of food systems responses to major trends.

\begin{tabular}{clll}
\hline $\begin{array}{c}\text { Outcome Areas Change } \\
\text { Drivers }\end{array}$ & \multicolumn{1}{c}{ Resilience } & \multicolumn{1}{c}{ Inclusiveness } & \multicolumn{1}{c}{ Sustainability } \\
\hline $\begin{array}{c}\text { Urbanisation and } \\
\text { Migration }\end{array}$ & $\begin{array}{l}\text { Regular supply, loss reduction } \\
\text { and stable prices of perishable } \\
\text { food (drying, cooling, } \\
\text { packaging) through consumer } \\
\text { market information (i.e., } \\
\text { mobile app) }\end{array}$ & $\begin{array}{l}\text { Access to healthy (fresh) } \\
\text { affordable food in (poor) } \\
\text { neighbourhoods with } \\
\text { high dietary gaps (i.e., } \\
\text { open markets, home } \\
\text { delivery) }\end{array}$ & $\begin{array}{l}\text { Food supply chains } \\
\text { based on transparent \& } \\
\text { responsive food } \\
\text { environment (grading; } \\
\text { food certification, etc.) }\end{array}$ \\
\hline \multirow{2}{*}{$\begin{array}{l}\text { Economic Growth } \\
\text { enhance food system } \\
\text { adaptation (i.e., smart } \\
\text { information and } \\
\text { communication technology } \\
\text { (ICT) solutions) }\end{array}$} & $\begin{array}{l}\text { Pro-poor targeting of } \\
\text { public and private } \\
\text { investments and } \\
\text { demand-led food } \\
\text { delivery options } \\
\text { (consumer coops) }\end{array}$ & $\begin{array}{l}\text { Guiding dietary change } \\
\text { in home and } \\
\text { out-of-home } \\
\text { consumption } \\
\text { (convenient \& healthy } \\
\text { diets) }\end{array}$ \\
\hline \multirow{2}{*}{$\begin{array}{l}\text { Farmer training and inputs } \\
\text { finance for mitigation and } \\
\text { adaptation }\end{array}$} & $\begin{array}{l}\text { De-risking of } \\
\text { smallholder finance (i.e., } \\
\text { pre-finance mechanisms) }\end{array}$ & $\begin{array}{l}\text { Early investments to } \\
\text { anticipate shifts in } \\
\text { appropriate production } \\
\text { areas and techniques }\end{array}$ \\
\hline
\end{tabular}

Source: author's elaboration.

Important external food systems challenges are related to rapid migration towards (peri-)urban settlements that may increase the likelihood of food losses and waste in longer-distance food chains, require more storage and processing facilities, and lead to changes in diets (more processed foods) and shifts in market outlets (supermarkets, convenience shops and restaurants) that might affect inclusiveness and resilience. Economic growth and rising incomes tend to modify the food demand of the middle classes towards convenience consumption, whereas poorer population segments search for protection against price fluctuation (e.g., through affiliation to consumer cooperatives). Food system responses to climate change require either fixed investments for adaptation of production systems (provided by international banks) and/or climate-smart finance for climate mitigation purposes (provided by NGOs). Finally, improved connectedness through ICT systems enables consumers to make more informed food choices and could eventually support demand-led shifts in consumer behaviour towards more sustainable products and healthier diets.

Identifying such cross-cutting solutions to enhance inclusive, responsive and resilient food systems performance requires concerted efforts by interdisciplinary teams that are committed to engage in an informed dialogue with food system stakeholders. Finding out-of-the-box alternatives implies that most attention should be given to an understanding of the food system interlinkages and feedbacks, and less to each of the separate components.

The integration of such transdisciplinary teams is usually built on joint training and knowledge exchange, strong commitment to learning and innovation, transparent information exchange and common understanding of the shared purpose that can only be reached through committed multi-stakeholder collaboration. Important new insights on suitable policy interventions and business innovations in response to external shocks tend to be generated at the interface between explorative 
analysis (inventory of change options) and interactive appraisal (portfolio of change pathways) that enable to overcome critical food system bottlenecks.

Therefore, it is of critical importance that food systems analysis is undertaken as part of a wider agenda of agrarian and social transformation. While adjustments of individual components could certainly be helpful to solve specific local problems, they do not change the overall dynamics of food systems interactions [48]. Moreover, identifying tools for creating synergies between food systems goals (i.e., healthy and sustainable food) can be better addressed when nested food system levels are simultaneously considered and payoffs to each of the stakeholders can be clearly acknowledged.

\section{Conclusions and Outlook}

Policies for influencing food systems' performance need to be based on an adequate understanding of both the relationships between key stakeholders as well as the interactions with the external environment. Many different instruments can be used to support safe and healthier food choices and to improve dietary outcomes, but their effectiveness cannot be generally acknowledged [49]. This is primarily due to the wide diversity in strategic responses amongst food system stakeholders and the dynamic feedbacks between different food system levels.

We outlined in this article some major analytical challenges for describing the structural components of food systems and for analysing opportunities for food systems change empirically. Given the complex interactions between different system levels and the strategic responses of each of the stakeholders, it is difficult to offer adequate foresight on possible pathways towards food systems transition [50]. Better understanding of (internal) leverage points and (external) drivers of system change, as well as timely identification of potential trade-offs between food system goals permits us to prioritize key policy interventions as enablers for business innovation practices.

Important insights from food systems analysis indicate that solutions to major food and nutrition challenges can be found in other parts of the system, sometimes far from the area where the problem became manifest. This may lead to another type of interventions that strategically rely on intersections with other systems, the interactions within the food system, or the incentives towards stakeholders, in order to identify actions that can improve food systems performance and ultimately support food systems transformation. Improving insights in dynamic adjustments pathways and strategic stakeholder responses can be very helpful for creating public-private coalitions that enable food systems change.

Based on experiences in food systems research and the parallel adjustment in leading paradigms for operational food policy analysis, we can identify three critical conditions that should be considered for an interactive analysis of food system transitions:

1. Multi-level interdependencies between food system activities permit focused actions towards leverage points that may result in coherent outcomes at aggregate system level;

2. Multiple goals optimization that are based on adaptive innovation practices and learning loops towards scaling of food systems' change strategies;

3. Multiple stakeholder activities that together are able to create synergies and multipliers that permit the bridging of trade-offs.

Therefore, it is of paramount importance to develop analytical tools that enable the assessment of the likely outcomes of nutrition-oriented public policies and investment priorities to evaluate empirically the effectiveness of different (sets of) instruments for satisfying key stakeholders' goals and for reaching strategic development objectives. Given the diverse and multi-level responses to policy incentives and simultaneously occurring changes in external conditions, broad coalitions between different (public and private/civic) stakeholders are necessary to overcome possible trade-offs.

Author Contributions: R.R.: first author, coordinator KB-22 theme "Global food and nutrition security" and CGIAR-A4NH Management Committee member. J.V., C.P.: coordinator KB-22 theme "Global food and nutrition security, Wageningen Research. 
Funding: This research received was funded by the Dutch Ministry of Agriculture, Nature and Food Quality, grant number KB-22.

Acknowledgments: The authors wish to thank the CGIAR-A4NH Flagship "Food Systems for Healthier Diets" funded by the Dutch Ministry of Foreign Affairs, and the KB-22 theme "Global food and nutrition security" of Wageningen University and Research funded by the Dutch Ministry of Agriculture, Nature and Food Quality for funding this study conducted under the Food Systems umbrella.

Conflicts of Interest: The authors declare no conflict of interest.

\section{References}

1. Van Ittersum, M.K.; Van Bussel, L.G.; Wolf, J.; Grassini, P.; Van Wart, J.; Guilpart, N.; Claessens, L.; de Groot, H.; Wiebe, K.; Mason-D'Croz, D. Can sub-saharan africa feed itself? Proc. Natl. Acad. Sci. USA 2016, 113, 14964-14969. [CrossRef] [PubMed]

2. Foran, T.; Butler, J.R.; Williams, L.J.; Wanjura, W.J.; Hall, A.; Carter, L.; Carberry, P.S. Taking complexity in food systems seriously: An interdisciplinary analysis. World Dev. 2014, 61, 85-101. [CrossRef]

3. Goodman, D.; DuPuis, E.M.; Goodman, M.K. Alternative Food Networks: Knowledge, Practice, and Politics; Routledge: Abingdon, UK, 2012.

4. Morley, A.; Marsden, T. Current food questions and their scholarly challenges: Creating and framing a sustainable food paradigm. In Sustainable Food Systems; Routledge: Abingdon, UK, 2014; pp. 17-45.

5. Pitt, H.; Jones, M. Scaling up and out as a pathway for food system transitions. Sustainability 2016, 8, 1025. [CrossRef]

6. Grant, M. A food systems approach for food and nutrition security. Sight Life 2015, 29, 87-90.

7. Herforth, A.; Ahmed, S. The food environment, its effects on dietary consumption, and potential for measurement within agriculture-nutrition interventions. Food Secur. 2015, 7, 505-520. [CrossRef]

8. Tschirley, D.; Haggblade, S.; Reardon, T. Africa's emerging food system transformation. In Global Center for Food Systems Innovation; White Paper; Michigan State University: East Lansing, MI, USA, 2013.

9. Dunning, R.; Bloom, J.D.; Creamer, N. The local food movement, public-private partnerships, and food system resiliency. J. Environ. Stud. Sci. Springer Assoc. Environ. Stud. Sci. 2015, 5, 661-670. [CrossRef]

10. Kjellberg, A.; Sohlenius, G. Principles of multidisciplinary cooperation in research, especially behavioural science and manufacturing. CIRP Ann. 1993, 42, 541-543. [CrossRef]

11. Scott, P. Global panel on agriculture and food systems for nutrition: Food systems and diets: Facing the challenges of the 21st century. Food Secur. Sci. Sociol. Econ. Food Prod. Access Food 2017, 9, 653-654. [CrossRef]

12. Ingram, J. A food systems approach to researching food security and its interactions with global environmental change. Food Secur. 2011, 3, 417-431. [CrossRef]

13. Westhoek, H.; Ingram, J.; Van Berkum, S.; Özay, L.; Hajer, M. Food systems and natural resources. In A Report of the Working Group on Food Systems of the International Resource Panel; United Nations Environment Programme: Paris, France, 2016.

14. Van Berkum, S.; Dengerink, J.; Ruben, R. The Food Systems Approach: Sustainable Solutions for a Sufficient Supply of Healthy Food; Wageningen Economic Research: Wageningen, The Netherlands, 2018.

15. Allen, T.; Prosperi, P. Modeling sustainable food systems. Environ. Manag. 2016, 57, 956-975. [CrossRef]

16. Shaping the Future of Global Food Systems: A Scenarios Analysis; World Economic Forum: Cologny, Switzerland, 2017.

17. Caron, P.; y de Loma-Osorio, G.F.; Nabarro, D.; Hainzelin, E.; Guillou, M.; Andersen, I.; Arnold, T.; Astralaga, M.; Beukeboom, M.; Bickersteth, S. Food systems for sustainable development: Proposals for a profound four-part transformation. Agron. Sustain. Dev. 2018, 38, 41. [CrossRef]

18. Bui, S.; Cardona, A.; Lamine, C.; Cerf, M. Sustainability transitions: Insights on processes of niche-regime interaction and regime reconfiguration in agri-food systems. J. Rural Stud. 2016, 48, 92-103. [CrossRef]

19. De Schutter, O. The political economy of food systems reform. Eur. Rev. Agric. Econ. 2017, 44, 705-731. [CrossRef]

20. Meadows, D. Places to intervene in a system. Whole Earth 1997, 91, 78-84.

21. Béné, C.; Oosterveer, P.; Lamotte, L.; Brouwer, I.D.; de Haan, S.; Prager, S.D.; Talsma, E.F.; Khoury, C.K. When food systems meet sustainability-current narratives and implications for actions. World Dev. 2019, 113, 116-130. [CrossRef] 
22. Fresco, L.O.; Ruben, R.; Herens, M. Challenges and perspectives for supporting sustainable and inclusive food systems. GREAT Insights Magazine, 2017; 13-15.

23. Eakin, H.; Connors, J.P.; Wharton, C.; Bertmann, F.; Xiong, A.; Stoltzfus, J. Identifying attributes of food system sustainability: Emerging themes and consensus. Agric. Hum.Values 2016, 34, 57-773. [CrossRef]

24. Sundaram, J. Tackling the nutrition challenge: A food systems approach. J. Dev. 2014, 2, 141. [CrossRef]

25. Gladek, E.; Fraser, M.; Roemers, G.; Sabag Muñoz, O.; Kennedy, E.; Hirsch, P. The Global Food System: An Analysis; Metabolic: Zeist, The Netherlands, 2016; p. 180.

26. Gillespie, S.; van den Bold, M. Agriculture, Food Systems, and Nutrition: Meeting the Challenge. 2017. Available online: https:/ / onlinelibrary.wiley.com/doi/pdf/10.1002/gch2.201600002 (accessed on 05 December 2017).

27. Lang, T. Food security and food sustainability: Reformulating the debate. Geogr. J. 2012, 178, $313-332$. [CrossRef]

28. Miller, D.; Welch, R.M. Food system strategies for preventing micronutrient malnutrition. Food Policy 2013, 42, 115-128. [CrossRef]

29. Hawkes, C. Policy coherence across the food system for nutrition: From challenge to opportunity. GREAT Insights Mag. 2017, 6. Available online: https:/ / ecdpm.org/great-insights/sustainable-food-systems/policycoherence-across-food-system-nutrition-challenge-opportunity/ (accessed on 12 August 2018).

30. Gereffi, G.; Fernandez-Stark, K. Global Value Chain Analysis: A Primer; Duke University: Durham, NC, USA, 2016.

31. Hunt, K.P. A nested approach to the right to food: Food security, gender violence, and human rights. J. Agric. Food Syst. Commun. Dev. 2016, 7, 141-143. [CrossRef]

32. Vandermeer, J.; Aga, A.; Allgeier, J.E.; Badgley, C.; Baucom, R.; Blesh, J.; Shapiro, L.F.; Jones, A.D.; Hoey, L.; Perfecto, I. Feeding prometheus: An interdisciplinary approach for solving the global food crisis. Front. Sustain. Food Syst. 2018, 2, 39. [CrossRef]

33. Miles, A.; DeLonge, M.S.; Carlisle, L. Triggering a positive research and policy feedback cycle to support a transition to agroecology and sustainable food systems. Agroecol. Sustain. Food Syst. 2017, 41, 855-879. [CrossRef]

34. Haddad, L.; Hawkes, C.; Waage, J.; Webb, P.; Godfray, C.; Toulmin, C. Food Systems and Diets: Facing the Challenges of the 21st Century; 2016. Available online: http:/ / openaccess.city.ac.uk/19323/ (accessed on 24 May 2018).

35. Tendall, D.; Joerin, J.; Kopainsky, B.; Edwards, P.; Shreck, A.; Le, Q.; Krütli, P.; Grant, M.; Six, J. Food system resilience: Defining the concept. Glob. Food Secur. 2015, 6, 17-23. [CrossRef]

36. Fresco, L.O. Challenges for food system adaptation today and tomorrow. Environ. Sci. Policy 2009, 12, 378-385. [CrossRef]

37. Drewnowski, A.; Team, T.E.I. The Chicago consensus on sustainable food systems science. Front. Nutr. 2017, 4, 74. [CrossRef] [PubMed]

38. Kim, D.; Anderson, V. System Archetype Basics, from Story to Structure; Pegasus communication. Inc.: Waltham, MA, USA, 1998.

39. Benton, T.; Fairweather, D.; Graves, A.; Harris, J.; Jones, A.; Lenton, T.; Norman, R.; O’Riordan, T.; Pope, E.; Tiffin, R. Environmental Tipping Points and Food System Dynamics; Global Food Security: Swindon, UK, 2017.

40. Biggs, R.; Carpenter, S.R.; Brock, W.A. Turning back from the brink: Detecting an impending regime shift in time to avert it. Proc. Natl. Acad. Sci. USA 2009, 106, 826-831. [CrossRef]

41. Ericksen, P.; Stewart, B.; Dixon, J.; Barling, D.; Loring, P.; Anderson, M.; Ingram, J. The value of a food system approach. Food Secur. Glob. Environ. Change 2010, 25, 24-25.

42. Ingram, J.; Ericksen, P.; Liverman, D. Food Security and Global Environmental Change; Routledge: Abingdon, UK, 2012.

43. Garnett, T. Three perspectives on sustainable food security: Efficiency, demand restraint, food system transformation. What role for lca. J. Clean. Prod. 2013, 30, 1e9.

44. West, P.C.; Gerber, J.S.; Engstrom, P.M.; Mueller, N.D.; Brauman, K.A.; Carlson, K.M.; Cassidy, E.S.; Johnston, M.; MacDonald, G.K.; Ray, D.K. Leverage points for improving global food security and the environment. Science 2014, 345, 325-328. [CrossRef]

45. Brown, L.; Deshpande, C.; Hill, C.; Lambrou, Y.; Laudazi, M.; Ragasa, C. Module 1: Gender and food security. In Gender and Agriculture Sourcebook: Investing in Women as Drivers of Agricultural Growth; 2009; 
Available online: http:/ / siteresources.worldbank.org/INTGENAGRLIVSOUBOOK/Resources/Module1. pdf (accessed on 12 October 2018).

46. Garnett, T.; Godfray, C.H. Sustainable Intensification in Agriculture. Navigating a Course through Competing Food System Priorities; University of Oxford Programme on the Future of Food, University of Oxford: Oxford, $\mathrm{UK}, 2012$.

47. Lang, T.; Barling, D. Nutrition and sustainability: An emerging food policy discourse. Proc. Nutr. Soc. 2013, 72, 1-12. [CrossRef] [PubMed]

48. Freedgood, J.; Pierce-Quiñonez, M.; Meter, K. Emerging assessment tools to inform food system planning. J. Agric. Food Syst. Commun. Dev. 2016, 2, 83-104. [CrossRef]

49. Pinstrup-Andersen, P.; Watson, D.D., II. Food Policy for Developing Countries: The Role of Government in Global, National, and Local Food Systems; Cornell University Press: Ithaca, NY, USA, 2011.

50. Thompson, J.; Millstone, E.; Scoones, I.; Ely, A.; Marshall, F.; Shah, E.; Stagl, S.; Wilkinson, J. Agri-Food System Dynamics: Pathways to Sustainability in an Era of Uncertainty. 2007. Available online: https://www.ids.ac.uk/ files/agriculture.pdf (accessed on 8 April 2016).

(C) 2018 by the authors. Licensee MDPI, Basel, Switzerland. This article is an open access article distributed under the terms and conditions of the Creative Commons Attribution (CC BY) license (http:/ / creativecommons.org/licenses/by/4.0/). 